\title{
ANALISIS KASUS ASFIKSIA PADA KEMATIAN NEONATAL DI RSUD TUGUREJO SEMARANG
}

\author{
Analysis Of Asfhyxia Case On Neonatal Death \\ In Rsud Tugurejo Semarang \\ Sri Puji Rahayu ${ }^{1}$, Sri Tjahjowati ${ }^{2}$ \\ STIKES HAKLI Semarang Semarang \\ (dr.sprahayu@gmail.com)
}

\begin{abstract}
ABSTRAK
Latar Belakang : Bayi hingga usia kurang satu bulan merupakan golongan umur yang memiliki risiko gangguan kesehatan paling tinggi, berbagai masalah kesehatan bisa muncul. Sehingga tanpa penanganan yang tepat, bisa berakibat fatal. Angka NDR yang tinggi tersebut terutama disebabkan karena angka kematian neonatal yang mencapai $90 \%$.

Tujuan : tujuan penelitian yaitu menganalisis kasus kematian neonatal berdasar karakteristik epidemiologi (orang, tempat, dan waktu).

Metode : Penelitian ini merupakan studi kuantitatif, yang dilakukan secara deskriptif dengan pendekatan waktu retrospektif. Populasi penelitian adalah seluruh kematian neonatal di salah satu rumah sakit pemerintah di Semarang tahun 2014 yang berjumlah 90 neonatal. Analisa data menggunakan metoda analisa deskriptif yaitu menganalisis data secara naratif, serta data dibandingkan dengan penelitian lain yang sejenis. Penelitian ini juga dilakukan analisa bivariate tentang hubungan beberapa karakteristik dengan kematian neonatal akibat asfiksia.

Hasil : Pada Tahun 2014, Kematian neonatal akibat asfiksia 90,9\% (70 bayi) terjadi pada usia 0-7 hari, $43(84 \%)$ berjenis kelamin laki-laki, $57(90,5 \%)$ karena BBLR dan sebesar $60(88,2 \%)$ panjang badan kurang dari $47 \mathrm{~cm}$ atau stunting. Berdasarkan karakteristik ibu, sebesar 50 (89,3\%) berusia 20-35 tahun, sebesar 47 $(87,0 \%)$ ibu dengan ANC < 4 kali, usia kehamilan ibu sebesar $42(88,9 \%)$ adalah 28-37 minggu, multipara dengan 2-4 anak sebesar 49 (92,5\%), pendidikan ibu SD dan SMP sebesar 62 (91,2\%),mengalami komplikasi kehamilan sebesar 61 $(91,0 \%)$ dan mengalami komplikasi selama persalinan sebesar 65 (91,5\%). Berdasarkan karakteristik tempat yaitu sebesar $53(86,9 \%)$ berasal dari pedesaan dan akses ke rumah sakit sebesar 40 (83,3\%) kurang dari 2 jam. Berdasarkan karakteristik waktu lama dirawat sebesar $40(88,9 \%)$ dirawat lebih dari 48 jam dan jarak anak dengan persalinan sebelumnya sebesar 47 (88,7\%) merupakan multipara dengan 2-4 anak. Penyebab Kematian neonatal akibat asfiksia pada penelitian ini sebesar $78(86,7 \%)$ dibandingkan non asfiksia sebesar $12(13,3 \%)$. Berdasar uji bivariat didapatkan ada hubungan antara umur neonatal $(\mathrm{P}=0,04)$, pendidikan ibu $(\mathrm{P}=0,027)$, komplikasi kehamilan $(\mathrm{P}=0,037)$, komplikasi persalinan $(\mathrm{P}=0,08)$ dan jarak anak $(\mathrm{P}=0,027)$ dengan kematian neonatal karena asfiksi.
\end{abstract}


Simpulan : Sebagian besar kasus kematian neonatal di RSUD Tugurejo dikarenakan asfiksia dan berhubungan dengan umur neonatal, pendidikan ibu, komplikasi kehamilan, komplikasi persalinan, dan jarak anak. Rumah Sakit perlu menyiapkan dokter jaga on site dan regonalisasi pelayanan kebidanan dan perinatal, perlunya ketersediaan informasi baik penyuluhan maupun konseling untuk ibu-ibu mengenai bahaya yang dapat terjadi dalam kehamilan persalinan dan masa nifas, upaya untuk menghindari masalah tersebut dan cara pemecahan masalah yang ada serta program Keluarga berencana (KB).

Kata kunci : epidemiologi, kematian neonatal, asfiksia

\section{ABSTRACT}

Background: Infants less than one month until the age of an age group that has the highest risk of health problems, many health problems can arise. So that without proper treatment, can be fatal. Figures NDR which was primarily due to higher neonatal mortality rate, which reached $90 \%$.

The purpose: the purpose of research is to analyze cases of neonatal mortality based on epidemiological characteristics (person, place and time) in RSU X Semarang.

Method : This research is a quantitative study, conducted descriptive Retrospective time. The population is all neonatal deaths in RSUD Tugurejo Semarang in 2014 amounting to 90 neonatal by the number of saturated samples. Data analysis uses descriptive analysis method that is analyzing data in narrative, and data compared with other similar studies. This study also carried out a bivariate analysis of the relationship of several characteristics with neonatal death due to asphyxia.

Result : Neonatal deaths due to asphyxia $90.9 \%$ (70 infants) were in the age of 0 7 days, 43 (84\%) male sex, 57 (90.5\%) due to low birth weight and by 60 (88.2\%) body length of less than $47 \mathrm{~cm}$ or stunting. based on the characteristics of the mother is at 50 (89.3\%) in the 20-35 years old, by 47 (87.0\%) of mothers with $A N C<4$ times, the age of the mother's pregnancy by $42(88.9 \%)$ is $28-37$ weeks, multiparous with 2-4 children by 49 (92.5\%), maternal education elementary and junior high for 62 (91.2\%), complications of pregnancy by 61 (91.0\%) and experienced complications during childbirth by 65 (91, 5\%). Based on the characteristics of a place that is equal to 53 (86.9\%) were from the countryside and access to hospitals by 40 (83.3\%) less than 2 hours. Based on the characteristics of a long time was treated for 40 (88.9\%) were treated for more than 48 hours and the distance children with previous deliveries by 47 (88.7\%) were multiparous with 2-4 children. Cause Neonatal deaths due to asphyxia in this study amounted to 78 (86.7\%) than non asphyxia by 12 (13.3\%). Based on bivariate test was no relationship between neonatal age $(P=0.04)$, maternal education $(P=0.027)$, complications of pregnancy $(P=0.037)$, birth complications $(P=0.08)$ and the spacing of children $(P=0.027)$ neonatal mortality due to asphyxiation. 
Conclusion : Most cases of neonatal death are due to asphyxia and are associated with neonatal age, maternal education, complications of pregnancy, complications of labor, and distance of birth. It is suggested that public hospitals need to prepare the attending physician on site and regonalisasi obstetric care and prenatal need for the availability of information both counseling and counseling for mothers about the dangers that can occur in pregnancy childbirth and postnatal, an attempt to avoid such problems and ways of solving the existing problems as well as family planning program (KB).

Key words : epidemiology, neonatal death, asphyxia

\section{PENDAHULUAN}

Permasalahan pokok yang dihadapi bangsa Indonesia adalah masalah kesehatan yang terjadi pada kelompok ibu dan anak, yang ditandai masih tingginya angka kematian ibu (AKI) dan angka kematian bayi (AKB). Kematian pada maternal dan bayi yang tinggi mencerminkan kemampuan negara dalam memberikan pelayanan kesehatan pada masyarakat belum baik. Angka kematian bayi terutama terjadi pada kematian neonatal atau bayi lahir mati atau meninggal pada bulan pertama dari kehidupannya. Sebagian besar kematian ini terjadi di negara berkembang termasuk Indonesia yaitu sekitar 7 (tujuh) juta bayi yang meninggal setiap tahun, kira-kira $2 / 3$ dari kelahiran bayi meninggal pada bulan pertama kehidupannya (Dinkes, Profil Kesehatan Jateng, 2014).

Hasil Riskesdas 2007 menunjukkan bahwa 78,5\% dari kematian neonatal terjadi pada umur 0-6 hari. Dengan melihat adanya risiko kematian yang tinggi dan berbagai serangan komplikasi pada minggu pertama kelahiran, maka setiap bayi baru lahir harus mendapatkan pemeriksaan sesuai standar. Penyebab kematian neonatal adalah bayi berat lahir rendah (BBLR) 30,3\%, dan penyebab utama lain kematian pada bayi adalah gangguan perinatal berupa Asfiksia sebesar 34,7\% (Triono, 2009). Hasil SDKI pada tahun 2010 tidak disebutkan angka kematian neonatal, hanya disebutkan bahwa kunjungan neonatus lengkap ke sarana kesehatan sampai 28 hari hanya sekitar 31,7\%. Masih dijumpai 11,1\% bayi yang dilahirkan dengan berat badan $<2500$ gram (Trihono, 2010). Pada SDKI tahun 2013 juga disebutkan kunjungan neonatus lengkap ke sarana kesehatan masih sekitar 39,3\%. Bayi yang lahir dengan berat badan < 2500 gram masih sekitar 10,2\% (Trihono, 2013).

Berbagai upaya untuk memperbaiki derajat kesehatan bayi lahir telah diterapkan di Indonesia tetapi hasilnya masih belum memuaskan. Sesuai dengan kesepakatan global, Indonesia diminta untuk menurunkan angka kematian bayi sebesar 17/1000 kelahiran hidup pada tahun 2019. Sehingga perlu dilakukan upaya yang lebih intensif untuk mempercepat laju penurunannya. Upaya pencegahan yang paling efektif adalah dengan melakukan usaha pemeliharaan dan pengawasan antenatal sedini mungkin, persalinan yang aman, serta perawatan yang baik. Salah satu caranya adalah mengetahui epidemiologi kasus kematian neonatal dan mengetahui faktor yang menyebabkan kematian neonatal tersebut. Upaya menurunkan angka kematian neonatal, merupakan prioritas utama 
kementerian kesehatan dalam mendukung pencapaian tujuan pembangunan milenium atau MDGs yang tertuang dalam Rencana Pembangunan Jangka Menengah Nasional 2015 - 2019. Salah satu strateginya adalah meningkatnya status kesehatan ibu dan anak dan meningkatkan akses dan mutu pelayanan kesehatan dan rujukan (Trihono, 2013).

Risiko terbesar kematian bayi baru lahir terjadi pada 24 jam pertama, minggu pertama dan bulan pertama kehidupannya yang disebut sebagai periode neonatal. Angka Kematian Neonatal (AKN) adalah jumlah kematian bayi berumur kurang dari 28 hari yang dicatat selama 1 tahun per 1000 kelahiran hidup pada tahun yang sama. Umumnya kematian neonatal disebabkan faktor yang dibawa sejak lahir, yang diperoleh dari orang tuanya pada saat konsepsi atau didapat selama kehamilan dan persalinan. Pada Rakor Institusi Pendidikan Tenaga Kesehatan Provinsi Jawa Tengah tahun 2014, Kepala Pusdiknakes (Pusat Pendidikan Tenaga Kesehatan) Provinsi Jateng menyampaikan bahwa jumlah penyebab kematian neonatal adalah BBLR 39,53 \%, Asfiksia 25,66 \%, Kelainan kongenital 12,90\% serta berbagai penyebab lainnya (Prasetyawati, 2012).

Menurut data dari Dinas Kesehatan Kota Semarang ( DKK ), angka kematian bayi baru lahir (neonatal) di Kota Semarang, Jawa Tengah, mengalami peningkatan dari tahun ke tahun. Meski peralatan pelayanan medis memadai namun jumlah kematian bayi baru lahir di Kota Semarang menduduki peringkat lima di Jawa Tengah. Jumlah kematian bayi baru lahir (neonatal) pada tahun 2011 sebesar 314 kasus, tahun 2012 sebesar 293 kasus dan tahun 2013 telah mencapai 206 kasus (Sumantri, 2014).

Fasilitas pelayanan kesehatan di Kota Semarang meliputi : 23 rumah sakit, 37 puskesmas, 13 puskesmas rawat inap, 79 dokter (SpOG), 525 bidan, dan 1.556 posyandu. Di Rumah Sakit X, jumlah kematian neonatal terbanyak terutama yang terjadi pada tahun 2014 dengan Angka Kematian Neonatal (AKN) selama lima tahun sebagai berikut : tahun 2010 AKN sebesar 42,28; tahun 2011, AKN sebesar 57,63; tahun 2012 AKN sebesar 53,77; tahun 2013 AKN sebesar 62,40 dan pada tahun 2014 AKN semakin tinggi sebesar 67,77 dari 1000 kelahiran hidup di RSU X Kota Semarang.

Hal tersebut menggambarkan bahwa Angka Kematian Neonatal (AKN) semakin meningkat dan mencapai 68 per 1000 kelahiran hidup pada tahun 2014. Sehingga perlu dilakukan kajian trilogi epidemiologi dan faktor determinan ibu yang menyebabkan tingginya angka kematian neonatal tersebut.

Fasiltas yang dimiliki rumah sakit tempat penelitian antara lain : jumlah tempat tidur 401 buah. Jumlah dokter ada 79 orang, diantaranya ada dokter spesialis Obsgyn 4 orang, perawat berjumlah 315 orang serta jumlah bidan 49 orang. Angka GDR (Gross Death Rate) sebesar 17\%, yaitu angka kematian umum untuk setiap 1000 penderita keluar. Angka NDR (Net Death Rate) sebesar 13\%, yaitu angka kematian lebih 48 jam setelah dirawat untuk tiap 1000 penderita keluar. Standar angka NDR adalah kurang dari $5 \%$. Menurut Kepala Rekam Medis permasalahan yang ada berdasarkan data rekam medis pasien setiap tahunnya yaitu angka kematian NDR yang tinggi yang disebabkan karena angka kematian neonatal ( $\mathrm{AKN}$ ) . Pada tahun 2013 meningkat dan mengalami 
peningkatan di tahun 2014 dengan jumlah total kematian neonatal 90 yang dirawat di Rumah Sakit.

Kematian sebesar 90 atau 67,77 dibanding 1000 kelahiran hidup tersebut sebagian besar $78(86,7 \%)$ akibat asfiksia, baik asfiksia berat maupun asfiksia sedang yang dapat dilihat dari nilai Apgar Score (AS) dan diagnosa dokter yang terulis pada dokumen rekam medis neonatal. Asfiksia adalah keadaan bayi tidak bernafas secara spontan dan teratur pada saat lahir atau beberapa saat setelah lahir. Neonatal yang mengalami asfiksia biasanya berkaitan dengan kondisi medis pada bayi itu sendiri, dan penyebab lain misalnya keadaan ibu, sistem pelayanan yaitu perawatan yang tidak adekuat selama kehamilan, persalinan dan perawatan post partum serta bayi baru lahir (Carr, 2014).

Dokumen rekam medis pada neonatal di rumah sakit sudah dipisahkan dari dokumen ibu dan diberi nomor rekam medis tersendiri. Rekam medis neonatal tersebut berisi tentang data identitas bayi, surat keterangan kematian, penyebab kematian, catatan perkembangan harian neonatal, demikian juga data rekam medis ibu. Kedua data tersebut dapat digunakan sebagai bahan dasar guna kajian epidemiologi dengan meneliti karakteristik orang (person), tempat (place) dan waktu (time) yang terkait dengan kematian neonatal akibat asfiksia tersebut.

Kajian epidemiologi adalah studi pendekatan epidemiologi yang bertujuan untuk menggambarkan masalah kesehatan yang terdapat di dalam masyarakat dengan menentukan frekuensi, distribusi dan determinan penyakit berdasarkan atribut dan karakteristik menurut segitiga epidemiologi (Orang, Tempat, dan Waktu). Karakteristik orang dalam epidemiologi kasus kematian neonatal meliputi : umur, jenis kelamin, berat badan lahir, panjang badan lahir, dan penyebab kematian. Karakteristik tempat meliputi : asal daerah kota atau desa dan akses ke pelayanan kesehatan. Sedangkan karakteristik waktu meliputi : waktu lam dirawat dan waktu dengan persalinan sebelumnya. Keterangan tentang orang, tempat dan waktu tersebut sangat erat hubungannya antara satu dengan yang lain, sehingga faktor tersebut diamati secara serentak. Perbedaan karakteristik individu secara tidak langsung dapat memberikan perbedaan pada keadaan keterpaparan maupun derajat risiko dan reaksi setiap individu (Noor, 2008)

Berdasarkan latar belakang yang telah diuraikan sebelumnya, maka perumusan masalah yang ada dijabarkan sebagai berikut: Angka NDR (Net Death Rate) pada tahun 2014 cukup tinggi, sebesar 13\%, yaitu angka kematian lebih 48 jam setelah dirawat untuk tiap 1000 penderita keluar. Standar angka NDR adalah kurang dari $5 \%$. NDR tersebut terutama disebabkan karena angka kematian neonatal yang tinggi, setiap tahun meningkat sampai mencapai 90 pada tahun 2014, yaitu Angka Kematian Neonatal (AKN) dari 62,40 per seribu kelahiran hidup pada tahun 2013 dibandingkan 67,77 per seribu kelahiran hidup pada tahun 2014. Sehingga penyebab kematian neonatal sebesar $78(86,7 \%)$ akibat asfiksia yang terjadi perlu dikaji kemudian perlu dilakukan studi secara trilogi epidemiologi yaitu karakteristik orang, tempat dan waktu pada kematian neonatal tersebut.Hasil karakteristik orang, tempat dan waktu untuk menggambarkan distribusi dan frekuensi serta derajat risiko dan reaksi setiap individu pada kasus kematian neonatal akibat asfiksia. Diharapkan hasil penelitian ini dapat untuk 
lebih mengetahui dari trilogi epidemiologi faktor mana yang paling berkaitan dengan kematian neonatal akibat asfiksia di RSUD Tugurejo Semarang.

\section{METODE PENELITIAN}

Penelitian ini merupakan studi kuantitatif, yang dilakukan secara deskriptif observatif dengan pendekatan waktu retrospektif (Dahlan, 2011). Variabel bebas meliputi karakteristik neonatal, karakteristik ibu, karakteristik tempat dan karakteristik waktu. Sedangkan variabel terikatnya adalah kematian neonatal. Populasi penelitian adalah seluruh kematian neonatal di rumah sakit tempat penelitian tahun 2014 yang berjumlah 90 neonatal dengan jumlah sampel jenuh.

Analisa data menggunakan metoda analisa deskriptif yaitu menganalisis data secara naratif, serta data dibandingkan dengan penelitian lain yang sejenis. Penelitian ini juga dilakukan analisa bivariate tentang hubungan beberapa karakteristik dengan kematian neonatal akibat asfiksia.

\section{HASIL DAN PEMBAHASAN}

\section{Karakteristik Neonatal}

Karakteristik Neonatal yang diteliti meliputi umur, jenis kelamin, berat badan lahir, dan panjang badan lahir. Data ini didapatkan dari rekam medis pasien yang dapat dilihat pada tabel 1 .

Tabel 1 Karakteristik Kematian Neonatal di RSUD Tugurejo Semarang Tahun

\begin{tabular}{|c|c|c|c|}
\hline No & Karakteristik Neonatal & Frekuensi & Persentase \\
\hline \multirow[t]{4}{*}{1} & Umur Kematian & & \\
\hline & a. $0-7$ hari & 77 & $85,6 \%$ \\
\hline & b. $8-28$ hari & 13 & $14,4 \%$ \\
\hline & Total & 90 & $100 \%$ \\
\hline \multirow[t]{4}{*}{2} & Jenis Kelamin & & \\
\hline & a. Laki - laki & 51 & $56,7 \%$ \\
\hline & b. Perempuan & 39 & $43,3 \%$ \\
\hline & Total & 90 & $100 \%$ \\
\hline \multirow[t]{4}{*}{3} & Berat Badan Lahir & & \\
\hline & a.BBLR & 63 & $70 \%$ \\
\hline & b.Normal & 27 & $30 \%$ \\
\hline & Total & 90 & $100 \%$ \\
\hline \multirow[t]{4}{*}{4} & Panjang Badan Lahir & & \\
\hline & a. $<47 \mathrm{~cm}$ & 68 & $75,6 \%$ \\
\hline & b. $>48 \mathrm{~cm}$ & 22 & $24,4 \%$ \\
\hline & Total & 90 & $100 \%$ \\
\hline
\end{tabular}

Pada tabel 1 terlihat bahwa jumlah kematian neonatal sebesar 90 kematian, meliputi kematian neonatal dini yaitu kematian bayi yang terjadi pada waktu lahir sampai dengan umur 7 hari setelah lahir sebesar 77 (85,6\%) dari seluruh kematian neonatal. Angka tersebut lebih besar daripada kematian neonatal 
lanjut, yaitu kematian yang terjadi setelah 7 hari lahir sampai usia 28 hari sebesar 13 kematian neonatal atau 14,4\%. Hal ini sesuai dengan penelitian Raharni (2011) yang menggunakan data Riskesdas tahun 2010 terdapat kematian neonatal dini sebesar 88,6\%. Periode minggu pertama setelah melahirkan merupakan masa yang rawan bagi neonatus, karena merupakan masa transisi dari kehidupan di dalam rahim ke kehidupan di dunia luar. Perlunya perbaikan upaya pertolongan dan perluasan pelayanan neonatal pada periode minggu pertama setelah persalinan akan mempertinggi peluang untuk menurunkan risiko kematian.

Kematian neonatal dilihat menurut gender, maka kematian neonatal pada laki-laki terdapat $51(56,7 \%)$ dan pada perempuan sebanyak $39(43,3 \%)$. Proporsinya adalah 1,3 kali lebih besar kematian neonatal pada bayi laki-laki dibanding dengan bayi perempuan. Kematian neonatal yang terjadi menurut gender ini, sesuai dengan penelitian Sugiharto (2010) dengan menggunakan data Riskesdas tahun 2007 dengan hasil 62,3\% kematian neonatal terjadi pada laki-laki.

Kematian neonatal berdasar berat badan lahir, maka dari 90 neonatal ada yang dilahirkan dengan berat lahir Low birth Weight (BBLR = Berat bayi lahir rendah) sebesar $63(70 \%)$ serta sebesar 27 (30\%) neonatal dilahirkan dengan berat badan normal. Berat badan lahir rendah ( kurang dari 2500 gram) merupakan salah satu faktor utama yang berkontribusi terhadap kematian neonatal. BBLR dibedakan dalam 2 kategori yaitu BBLR karena prematur (usia kandungan kurang dari 37 minggu) atau BBLR karena intrauterine growth retardation (IUGR). Di Negara berkembang termasuk Indonesia, BBLR dikaitkan dengan kondisi ibu akibat gizi buruk, anemia dan penyakit lainnya.

Panjang badan lahir neonatal 68 (75,6\%) termasuk pendek yaitu kurang dari $47 \mathrm{~cm}$, sedangkan $22(24,4 \%)$ yang termasuk panjang badan normal dari seluruh kematian neonatal. Panjang atau tinggi badan lahir memberikan gambaran tentang keadaan gizi ibu dan janin. Untuk pertama kali tahun 2013 Riskesdas juga mengumpulkan data panjang bayi lahir. Hasilnya angka nasional untuk stunting atau lahir pendek $(<48 \mathrm{~cm}$ ) sebesar 20,2\% (Trihono, 2013).

\section{Karakteristik Ibu}

Karakteristik ibu terdiri dari umur, ante natal care, usia kehamilan, paritas, pendidikan ibu, komplikasi pada kehamilan, dan komplikasi pada persalinan.

Tabel 2 Karakteristik Ibu Pada Kasus Kematian Neonatal di RSUD Tugurejo Semarang Tahun 2014

\begin{tabular}{llcc}
\hline No & \multicolumn{1}{c}{ Karakteristik Ibu } & Frek. & \% \\
\hline 1 & Umur Ibu & 34 & $37,8 \%$ \\
& a. $<20$ th, $>35$ th & 56 & $62,2 \%$ \\
& b. $20-35$ tahun & 90 & $100,0 \%$ \\
& Total & & \\
2 & ANC (ante natal care) & 54 & $60 \%$ \\
& a. $<4$ kali & 36 & $40 \%$ \\
& b. $\geq 4$ kali & 90 & $100 \%$
\end{tabular}




\begin{tabular}{|c|c|c|c|}
\hline \multirow[t]{4}{*}{3} & Usia Kehamilan & & \\
\hline & a. $28-37 \mathrm{mg},>42 \mathrm{mg}$ & 47 & $52,2 \%$ \\
\hline & b. $38-42 \mathrm{mg}$ & 43 & $47,8100,0 \%$ \\
\hline & Total & 90 & \\
\hline \multirow[t]{4}{*}{4} & Paritas & & \\
\hline & $\begin{array}{l}\text { a. Primipara dan } \\
\text { Grandemultipara }\end{array}$ & 37 & $41,1 \%$ \\
\hline & b. Multipara (2-4 anak) & 53 & $58,9 \%$ \\
\hline & Total & 90 & $100,0 \%$ \\
\hline \multirow[t]{4}{*}{5.} & Pendidikan Ibu & & \\
\hline & a. SD dan SMP & 68 & $75,6 \%$ \\
\hline & b. SMA / PT & 22 & $24,4 \% 100,0 \%$ \\
\hline & Total & 90 & \\
\hline \multirow[t]{4}{*}{6} & $\begin{array}{l}\text { Komplikasi Ibu pada kehamilan } \\
\text { a. Ada komplikasi }\end{array}$ & & \\
\hline & b. Tdk ada komplikasi & 67 & $74,4 \%$ \\
\hline & Total & 23 & $25,6 \% 100,0 \%$ \\
\hline & & 90 & \\
\hline \multirow[t]{4}{*}{7} & Komplikasi ibu pada persalinan & & \\
\hline & a.Ada Komplikasi & & \\
\hline & b.Tidak ada Komplikasi & 71 & $78,8 \%$ \\
\hline & Total & 19 & $21,2 \% 100,0 \%$ \\
\hline
\end{tabular}

Pada usia ibu, ternyata umur ibu saat melahirkan pada kurun usia 20 35 tahun justru yang paling banyak mengalami kematian neonatal ini, yakni sebanyak 56 ( 62,2\%), sedangkan umur ibu di bawah 20 tahun dan yang lebih 35 tahun yang mengalami kematian neonatal sebanyak 34 (37,8\%) Umur Ibu yang optimal untuk melahirkan adalah 20 sampai dengan 35 tahun. Menurut teori umur Ibu di bawah 20 tahun dianggap belum cukup matang dalam menghadapi kehamilan dan persalinan, sehingga belum siap secara fisik dan mental. Sebaliknya jika umur ibu lebih dari 35 tahun, cenderung mengalami berbagai gangguan dan penyakit. Pertambahan umur akan diikuti perubahan perkembangan organ-organ dalam pelvis. Keadaan ini akan mempengaruhi kehidupan janin dalam rahim.

Ante Natal Care (ANC) yang dilakukan ibu, sebagian besar yaitu 54 (60\%) masih dibawah 4 kali dan 36 (40\%) yang sudah melakukan ANC minimal 4 kali atau lebih pada kasus kematian neonatal. Pemeriksaan ANC secara berkala sangat penting dilakukan, karena merupakan salah satu upaya koreksi terhadap penyimpangan yang ditemukan. Tujuan utama ANC adalah untuk menjaga agar ibu hamil dapat melalui masa kehamilan, persalinan dan nifas dengan baik serta selamat juga bayinya. Di Indonesia kematian neonatal akibat ibu tidak mendapatkan pelayanan ANC sebesar seperlima dibandingkan ibu yang mendapatkan pelayanan ANC (Unicef Indonesia, 2012).

Usia kehamilan ibu pada kasus kematian neonatal, sebagian besar adalah baru berusia 28 - 37 (preterm) dan ibu yang melahirkan lewat waktu atau (posterm / serotinus) sebesar 47 (52,2\%). Dibandingkan dengan ibu yang melahirkan cukup waktu 38 - 42 minggu sebesar 43 (47,8\%). Usia kehamilan ini preterm dan posterm merupakan risiko untuk terjadinya kematian neonatal. Hal ini berkaitan dengan kematangan dan fungsi organ-organ neonatal untuk kesiapan kehidupan di luar kandungan. Kelainan yang sering terjadi sehubungan dengan usia kehamilan yang belum matang adalah asfiksia. 
Paritas ibu, kematian neonatal yang terjadi banyak pada primipara dan grandemultipara sebesar $37(41,1 \%)$ dibandingkan kematian neonatal yang terjadi pada multigravida $53(58,9 \%)$. Kehamilan yang paling optimal adalah kehamilan kedua sampai dengan keempat. Ibu primipara dan grandemultipara mempunyai banyak faktor risiko untuk terjadinya kematian pada neonatal. Hal ini akan lebih buruk lagi pada kasus dengan jarak kehamilan yang singkat.

Pada pendidikan ibu, sebagian ibu yang mengalami kematian neonatal adalah berpendidikan SD dan SMP sebesar 68 (75,6\%) dibandingkan ibu yang lulusan yang lulusan SMA serta akademi sebesar 22 (24,4\%). Tingkat pendidikan berkaitan erat dengan tingkat kesehatan. Hal ini disebabkan oleh perilaku dan pengetahuan tentang kesehatan yang lebih baik pada ibu-ibu yang berpendidikan tinggi. Semakin tinggi tingkat pendidikan, semakin mudah menerima informasi yang diterima. Sehingga dapat melaksanakan konsep hidup sehat, mandiri, kreatif dan berkesinambungan.

Pada riwayat adanya komplikasi selama kehamilannya, ibu pada kasus kematian neonatal yang mengalami komplikasi ada $67(74,4 \%)$ sedangkan ibu yang tidak mengalami komplikasi selama kehamilannya sebesar $23(25,6 \%)$. Berdasarkan data rekam medis ibu komplikasi yang terjadi selama kehamilan berupa riwayat abortus sebelumnya, hipertensi dan atau pre eklampsi serta infeksi yaitu ibu menderita demam berdarah. Hal ini sesuai dengan teori yang ada, bahwa komplikasi yang terjadi selama kehamilan akan secara langsung menyebabkan kematian neonatal. Juga sesuai dengan penelitian Paula MS yang meneliti rumah sakit dengan pelayanan tersier kematian perinatal akibat komplikasi kehamilan yaitu hipertensi dan infeksi intrauterin.

Pada kasus komplikasi selama persalinan, ibu pada kasus kematian neonatal ini sebagian besar mengalami komplikasi selama persalinannya sebesar $71(78,8 \%)$ sedangkan ibu yang tanpa komplikasi selama bersalin sebesar 19 (21,2\%). Komplikasi yang terjadi selama persalinan ini adalah bayi lahir prematur, kelainan letak/posisi bayi yang dilahirkan, atonia uteri dan placenta previa atau perdarahan. Peran kesehatan ibu ketika hamil, perawatan yang tidak adekuat dan tidak tepat selama hamil, bersalin dan beberapa jam setelah melahirkan juga mempunyai konsekuensi terhadap terjadinya kematian bayi baru lahir.

\section{Karakteristik Tempat}

Karakteristik tempat terdiri dari tempat asal neonatal dan akses ke rumah sakit, disajikan dalam Tabel 3 berikut.

Tabel 3 Karakteristik Tempat pada Kematian Neonatal di RSUD Tugurejo Semarang Tahun 2014

\begin{tabular}{llcc}
\hline No & \multicolumn{1}{c}{ Karakteristik Tempat } & Frek. & \% \\
\hline $1 \quad$ Tempat Asal Neonatal & 61 & $67,8 \%$ \\
& a. Perdesaan & 29 & $32,2 \%$ \\
& b. Perkotaan & 90 & $100 \%$ \\
& Total & & \\
2 & Akses ke rumah Sakit & 48 & $53,3 \%$ \\
& a. $<2$ jam & 42 & $46,7 \%$ \\
& b. $>2$ jam & 90 & $100 \%$ \\
\hline
\end{tabular}


Pada tabel 3 karakteristik tempat asal neonatal dilahirkan adalah sebagian besar $61(67,8 \%)$ adalah tinggal di daerah pedesaan dan $29(32,2 \%)$ yang tinggal di daerah perkotaan. Hal ini sesuai dengan penelitian Mugeni,dkk yaitu kematian bayi yang berasal dari pedesaan sebesar 75\%. Hasil Riskesdas juga menyebutkan kematian bayi $0-11$ bulan sekitar $51,3 \%$ terjadi di pedesaan dan $48,7 \%$ pada bayi tersebut terjadi pada umur neonatal.

Akses ke rumah sakit pada kasus kematian neonatal ini sebesar 48 $(53,3 \%)$ yang dicapai dalam waktu lebih dari dua jam karena mereka tinggal di luar kota. Sebesar $42(46,7 \%)$ akses mereka masih di bawah 2 jam menuju rumah sakit karena masih tinggal di dalam kota dan daerah pinggiran sekitar rumah sakit. Akses ke rumah sakit merupakan masalah keterlambatan kedua penyebab kematian neonatal di negara-negara berkembang termasuk Indonesia. setelah terlambat pertama yaitu terlambat dalam mengambil keputusan untuk mencari perawatan kesehatan apabila terjadi komplikasi obsteri. Jangkauan ini dilihat dari jenis moda transportasi, waktu tempuh dan biaya menuju fasilitas kesehatan tersebut. Kendala di lapangan mengakibatkan banyak rumah sakit rujukan tidak dapat ditempuh dalam waktu 2 jam, yaitu merupakan waktu maksimal yang diperlukan untuk menyelamatkan ibu dengan perdarahan dari jalan lahir.

\section{Karakteristik Waktu}

Karakteristik waktu adalah waktu lama dirawat dan selang waktu dengan persalinan sebelumnya, disajikan pada tabel 4.

Tabel 4 Karakteristik Waktu pada Kematian Neonatal di RSUD Tugurejo Semarang Tahun 2014

\begin{tabular}{llcc}
\hline No & \multicolumn{1}{c}{ Karakteristik Waktu } & Frek. & \% \\
\hline 1 & Waktu lama dirawat & 45 & $50 \%$ \\
& a. Kurang 48 jam & 45 & $50 \%$ \\
& b. Lebih dari 48 jam & 90 & $100 \%$ \\
& Total & & \\
2 & Selang Waktu dengan persalinan & & \\
& sebelumnya & & \\
& a. Anak Pertama , & 68 & $75,5 \%$ \\
& $\quad<$ th atau > 4 th & & $24,5 \%$ \\
& b. $2-4$ tahun & 22 & $100 \%$ \\
& Total & 90 &
\end{tabular}

Pada tabel 4 karakteristik waktu yaitu lama dirawat, kematian neonatal terbesar terjadi pada kematian yang waktu perawatan nya kurang dari 48 jam sebesar 45 (50\%) dibandingkan mereka yang dirawat lebih dari 48 jam sebesar $45(50 \%)$. Keterlambatan ketiga dari penyebab kematian neonatal adalah terlambat dalam memperoleh perawatan di fasilitas kesehatan. Seringkali para ibu harus menunggu selama beberapa waktu karena manajemen dan fasilitas yang kurang memadai. Apalagi pada saat itu rumah sakit baru menerapkan dokter jaga on call artinya pada saat ada ibu akan bersalin, baru dokter akan dihubungi oleh petugas rumah sakit. Tetapi sejak tahun 2016 ini sudah ada dokter jaga obsgyn yang siap 24 jam di rumah sakit. Waktu lama dirawat 48 
jam ini berkaitan dengan penanganan yang dilakukan di rumah sakit maupun keterlambatan rujukan. Yaitu pada pasien yang meninggal sebelum 48 jam maka keadaan pasien tersebut sudah dianggap jelek sehingga kematiannya dianggap akibat keterlambatan rujukan.

Selang waktu antara persalinan sekarang dengan persalinan sebelumnya adalah sebagian besar merupakan anak pertama, kurang dari 2 tahun atau lebih dari 4 tahun sebesar $68(75,5 \%)$ dibandingkan mereka yang selang waktu dengan persalinan sebelumnya $2-4$ tahun sebesar 22 (22,5\%). Selang waktu persalinan optimal adalah antara 2 sampai 4 tahun dengan persalinan sebelumnya. Neontal yang dilahirkan dibawah 2 tahun, maka rahim dan dan kesehatan ibu belum pulih dengan baik. Kehamilan ini perlu diwaspadai karena adanya kemungkinan pertumbuhan janin yang kurang baik, persalinan lama dan terjadinya kematian neonatal. Sebaliknya jika jarak kehamilan lebih dari 4 tahun, disamping usia ibu yang sudah bertambah juga mengakibatkan persalinan berlangsung seperti kehamilan pertama.

\section{Penyebab Kematian}

Tabel 5 Penyebab Kematian Neonatal di RSUD Tugurejo Semarang Tahun 2014

\begin{tabular}{llcc}
\hline No & Penyebab Kematian & Frek. & \% \\
\hline 1 & Asfiksia & 78 & $86,7 \%$ \\
2 & Non Asfiksia : & 12 & $13,3 \%$ \\
& Aspirasi & $(3)$ & \\
& Infeksi : Pneumonia & $(2)$ & \\
& Birth Injury & $(2)$ & \\
& Feeding Problem & $(2)$ & \\
& Malform congenital & $(3)$ & $100 \%$ \\
\hline
\end{tabular}

Penyebab kematian neonatal terbesar di RSU X adalah asfiksia dengan jumlah $78(86,7 \%)$ dan yang non asfiksia sebesar $12(13,3 \%)$ sebagai akibat dari aspirasi, infeksi berupa pneumonia neonatal, birth injury, feeding problem dan malformasi congenital. Menurut penelitian Paula MS (2014) penyebab kematian perinatal pada rumah sakit layanan sekunder adalah asfiksia dengan nilai apgar score dibawah 7. Asfiksia adalah kegagalan nafas secara spontan dan teratur pada saat lahir atau beberapa saat setelah lahir. Penilaian bayi segera setelah lahir dengan Apgar Score (AS) pada menit pertama, menit ke lima dan menit ke 10, penting dilakukan. Pada bayi normal atau vigorous baby maka nilai Apgar Score berkisar antara 7 - 10. Pada asfiksia sedang nilai AS 4-6, sedangkan pada asfiksia berat nilai AS $0-3$.

\section{Analisa Bivariat}

\section{Karakteristik Neonatal Dengan Kematian Akibat Asfiksia Pada Neonatal}

Karakteristik neonatal yang diteliti meliputi : umur neonatal, jenis kelamin, berat badan lahir dan panjang badan lahir, bila dihubungkan dengan asfiksia pada kematian neonatal maka hasilnya adalah :

Tabel 6 Karakteristik Neonatal dengan Penyebab Kematian Akibat Asfiksia RSUD Tugurejo Semarang Tahun 2014 
Jurnal Kebidanan Indonesia. Vol 10 No 1. Januari 2019 (56 - 73)

\begin{tabular}{|c|c|c|c|}
\hline \multirow[t]{2}{*}{ No } & \multirow[t]{2}{*}{ Karakteristik Neonatal } & \multicolumn{2}{|c|}{ Penyebab Kematian } \\
\hline & & Asfiksia & Non Asfiksia \\
\hline \multirow[t]{3}{*}{1} & Umur Kematian & & \\
\hline & a. $0-7$ hari & $70(90,9 \%)$ & $7(9,1 \%)$ \\
\hline & b. $8-28$ hari & $8(61,5 \%)$ & $5(38,5 \%)$ \\
\hline \multirow[t]{3}{*}{2} & Jenis Kelamin & & \\
\hline & a. Laki - laki & $43(84,3 \%)$ & $8(15,7 \%)$ \\
\hline & b. Perempuan & $35(89,7 \%)$ & $4(10,3 \%)$ \\
\hline \multirow[t]{3}{*}{3} & Berat Badan Lahir & & \\
\hline & a.BBLR & $57(90,5 \%)$ & $6(9,5 \%)$ \\
\hline & b.Normal & $21(77,2 \%)$ & $6(22,2 \%)$ \\
\hline \multirow[t]{3}{*}{4} & Panjang Badan Lahir & & \\
\hline & a.Short $(<47 \mathrm{~cm})$ & $60(88,2 \%)$ & $8(11,8 \%)$ \\
\hline & b.Normal $(>48 \mathrm{~cm}$ ) & $18(81,8 \%)$ & $4(18,2 \%)$ \\
\hline
\end{tabular}

Tabel 6 memperlihatkan kematian neonatal tertinggi akibat asfiksi terjadi pada umur 0 - 7 hari sebesar $70(90,9 \%)$ dibandingkan yang non asksia sebesar $7(9,1 \%)$, sedangkan umur kematian $8-28$ hari akibat asfiksia terjadi pada $8(61,5 \%)$ kasus dan yang karena non asfiksia $12(13,3 \%)$.

Jenis kelamin laki laki mempunyai proporsi sebesar $43(84,3 \%)$ mengalami asfiksia dibandingkan dengan yang non asfksia yatu sebesar 6 $(15,7 \%)$. Pada bayi perempuan proporsi untuk terjadi asfiksi sebesar 35 $(89,7 \%)$ dibandingkan yang tidak asfiksia dengan jumlah $4(10,3 \%)$

Berat badan lahir rendah (BBLR) berkontribusi terhadap terjadinya asfiksia sebesar $57(90,5 \%)$ dibanding yang BBLR yang tidak mengalami asfiksia. Asfiksia adalah salah satu penyebab utama kejadian kematian pada neonatal dini, sehingga status BBLR memiliki pengaruh terhadap terhadap kematian neonatal dini ini. Hal ini karena BBLR merupakan keadaan yang sangat rentan dan memiliki potensi yang sangat besar untuk mudah mengalami gangguanlain seperti hipotermi, hipoglikemi, ikterus dan masalah kesehatan lain yang bila tidak ditangani dengan benar akan dapat terjadi kematian (Abdullah, 2015).

Panjang badan lahir neonatal yang mengalami asfiksi tergolong pendek yaitu sebesar $60(88,2 \%)$ dibanding neonatal pendek yang non asfiksia sebesar $8(11,8 \%)$.

\section{Karakteristik Ibu dengan Kematian Akibat Asfiksia pada Neonatal}

Tabel 7 Karakteristik Ibu Neonatal dengan Penyebab Kematian Akibat Asfiksia RSUD Tugurejo Semarang Tahun 2014

\begin{tabular}{|c|c|c|c|}
\hline \multirow[t]{2}{*}{ No } & \multirow{2}{*}{ Karakteristik Ibu Neonatal } & \multicolumn{2}{|c|}{ Penyebab Kematian } \\
\hline & & Asfiksia & Non Asfiksia \\
\hline \multirow[t]{3}{*}{1} & Umur Ibu & & \\
\hline & a. $<20$ th , $>35$ th & $28(82,4 \%)$ & $6(17,6 \%)$ \\
\hline & b. $20-35$ tahun & $50(89,3 \%)$ & $6(10,7 \%)$ \\
\hline \multirow[t]{3}{*}{2} & ANC (ante natal care) & & \\
\hline & a. $<4$ kali & $47(87,0 \%)$ & $7(13,0 \%)$ \\
\hline & b. $>4$ kali & $31(86,1 \%)$ & $5(13,9 \%)$ \\
\hline \multirow[t]{2}{*}{3} & Usia Kehamilan & & \\
\hline & a. $28-37 \mathrm{mg}$ dan $>42 \mathrm{mg}$ & $42(88,9 \%)$ & $5(11,1 \%)$ \\
\hline
\end{tabular}


Jurnal Kebidanan Indonesia. Vol 10 No 1. Januari 2019 (56 - 73)

\begin{tabular}{|c|c|c|c|}
\hline \multirow{4}{*}{4} & b. $38-42 \mathrm{mg}$ & $36(84,4 \%)$ & $7(15,6 \%)$ \\
\hline & Paritas & & \\
\hline & a. Primipara dan & $29(78,4 \%)$ & $8(21,6 \%)$ \\
\hline & grandemultipara & $49(92,5 \%)$ & $4(7,5 \%)$ \\
\hline \multirow{4}{*}{5} & b. Multipara (2-4 anak) & & \\
\hline & Pendidikan Ibu & & \\
\hline & a. SD dan SMP & $62(91,2 \%)$ & $6(8,8 \%)$ \\
\hline & b. SMA / PT & $16(72,7 \%)$ & $6(27,3 \%)$ \\
\hline \multirow[t]{4}{*}{6} & Komplikasi Ibu pada & & \\
\hline & kehamilan & $61(91,0 \%)$ & $6(9,0 \%)$ \\
\hline & a. Ada komplikasi & $17(73,9 \%)$ & $6(26,1 \%)$ \\
\hline & b. Non komplikasi & & \\
\hline \multirow[t]{4}{*}{7} & Komplikasi ibu pada & & \\
\hline & persalinan & $65(91,5 \%)$ & $6(8,5 \%)$ \\
\hline & a.Ada Komplikasi & $13(68,4 \%)$ & $6(31,6 \%)$ \\
\hline & b.Non Komplikasi & & \\
\hline
\end{tabular}

Pada tabel 7, umur ibu yang berkontribusi terhadap kematian neonatal adalah 20 -35 tahun sebesar 50 (89,3\%) dibandingkan yang non asfiksia sebesar $6(10,7 \%)$. Padahal menurut teori umur ibu merupakan salah satu faktor yang sangat mempengaruhi kematian neonatal. Risiko kematian neonatal yang tinggi terjadi pada ibu yang berumur dibawah 20 tahun dan yang berumur lebih dari 35 tahun. Rentang umur 20 - 35 tahun adalah periode paling aman untuk melahirkan karena organ-organ reproduksi telah berkembang dengan sempurna (Zulkifli, 2012).

Pemeriksaan ANC dilakukan untuk mengetahui kesehatan ibu hamil dan perkembangan bayi yang dikandung sehingga diharapkan dapat mencapai kesehatan yang optimal untuk menghadapi masa persalinan, masa nifas dan laktasi. Pemeriksaan ANC yang dianjurkan adalah minimal 4 kali dalam masa kehamilan, meliputi 1 kali pemeriksaan pada trimester pertama, minimal 1 kali pemeriksaan pada trimester kedua dan minimal 2 kali pada trimester ketiga. Pada pemeriksaaan ANC yang sesuai standar ini diharapkan selama kehamilan, persalinan dan nifas ibu tetap sehat. Sehingga bayi bayi yang dilahirkan juga sehat,kemudian dapat menurunkan morbiditas dan mortalitas maternal dan neonatal. Pada penelitian ini, sebesar $47(87,0 \%)$ ibu yang ANC kurang dari 4 kali bayinya mengalami asfiksia dibandingkan 7 (13,0\%) yang non asfiksia, hal ini sesuai dengan penelitian Andi Zulkifli, 2012 bahwa bayi yang ANC kurang dari 4 kali mengalami kematian neonatal sebesar $40 \%$ (Zulkifli, 2012).

Usia kehamilan ibu premature yaitu 28 -37 minggu sebesar $42(88,9 \%)$ berkontribusi untuk terjadi asfiksia dibandingkan dengan yang non asfiksia sebesar $5(11,1 \%)$. Pada penelitian ini tidak ada ibu yang melahirkan lewat waktu 42 minggu atau serotinus.

Paritas adalah jumlah anak yang telah dilahirkan oleh seorang ibu yang berakhir dengan lahir hidup ataupun lahir mati. Ibu primipara yaitu baru pertama melahirkan dan grandemultipara yaitu anak lebih dari 4 mempunyai risiko untuk kematian neonatal. Hal ini terjadi karena ibu yang sering melahirkan mempunyai risiko bagi kesehatannya juga kesehatan anaknya. Pada 
Paritas primigravida jalan lahir belum teruji dan secara psikis ibu belum terlatih dalam upaya perawatan janin.

Pendidikan ibu SD - SMP atau rendah sebesar 62 (91,2\%) berkontribusi untuk mengakibatkan asfiksia hal ini dikarenakan rendahnya pengetahuan ibu mengenai tanda-tanda bahaya bagi neonatal dan kehamilannya yang merupakan faktor resiko utama kematian neonatal. Walaupun pendidikan tidak akan secara langsung berdampak positip kepada terhadap penurunan resiko kematian neonatal. Tetapi hal tersebut menunjukkan pentingnya deteksi dini akan penyakit yang sering dialami ibu dan neonatal sebagai langkah kelangsungan hidup neonatal. Penelitian di Makasar menyebutkan bahwa pendidian ibu yang rendah berkontribusi terhadap kematian neonatal dini denga nilai OR sebesar 2,905 (Utomo, 2011).

Komplikasi Ibu pada waktu kehamilan juga berkontribusi besar terhadap asfiksia yang menyebabkan kematian neonatal yaitu sebesar 61 (91,0\%) dibandingkan dengan yang non asfiksia sepesar 6(8,5\%). Komplikasi yang dijumpai pada penelitian ini yang terjadi pada ibu selama kehamilan adalah ibu mengalami hiperteni yang baik yang berkembang menjadi preeklampsi maupu eklampsi. Selain itu beberapa ibu pernah mengalami riwayat abortus sebelumnya, ada riwayat perdarahan selama kehamilan nya ini dan ada ibu mengalami infeksi berupa thipoid pada saat hamil. Penyakit-penyakit saat hamil tersebut sangat berisiko terhadap kesehatan dan kematian neonatal yang dilahirkannya.

Komplikasi ibu pada saat persalinan sebesar 65 (91,5\%) terjadi asfiksia pada neonatal yang menyebabkan kematiannya dibanding $6(8,5 \% 0$ yang non asfiksia. Pada penelitian ini komplikasi yang dijumpai pada saat persalinan yaitu lahir secara prematur, persalinan dengan tindakan yaitu vaccum dan versi ekstraksi , ketuban pecah dini dan perdarahan. Komplikasi kehamilan ini tertulis dalam rekam medis yang diidentifikasi dari laporan ibu, bukan diagnosa dokter secara khusus yang menemukan kmplikasi tersebut saat kehamilannya. Menurut penelitian di NTT tentang faktor risiko kematian neonatal dini di RS bersalin kematian neonatal akibat komplikasi ini 80 kali lebih tingggi (Zulkifli, 2012).

\section{Karakteristik Tempat dengan Kematian Akibat Asfiksia pada Neonatal}

Tabel 8 Karakteristik Tempat dengan Penyebab Kematian Akibat Asfiksia RSUD Tugurejo Semarang Tahun 2014

\begin{tabular}{clcc}
\hline \multirow{2}{*}{ No } & \multirow{2}{*}{ Karakteristik Tempat } & \multicolumn{2}{c}{ Penyebab Kematian } \\
\cline { 3 - 4 } & Tempat Asal Ibu & Asfiksia & Non Asfiksia \\
\hline & a. Pedesaan & $53(86,9 \%)$ & $8(13,1 \%)$ \\
& b. Perkotaan & $25(86,2 \%)$ & $4(13,8 \%)$ \\
\multirow{2}{*}{2} & & & \\
& Akses ke RS & & \\
& a. $<2$ jam & $40(83,3 \%)$ & $8(16,7 \%)$ \\
& b. $>2$ jam & $38(90,5 \%)$ & $4(9,5 \%)$ \\
\hline
\end{tabular}


Pada tabel 8 karakteristik tempat asal ibu sebesar 53 (86,9\%) tinggal di pedesaan yang mengalami asfiksia yang mengakibatkan kematian dibandingkan dengan $8(13,1 \%)$ yang non asfiksia. Akses ke rumah sakit yang kurang dari 2 jam sebesar $40(83,3 \%)$ ternyata mengalami asfiksia dibandingkan yang mempunyai akses lebih dari 2 jam. Hal ini membuktian bahwa sebenarnya akses menuju rumah sakit relatif mudah dibandingkan daerah lain di Indonesia (Utomo, 2011).

\section{Karakteristik Waktu dengan Kematian Akibat Asfiksia pada Neonatal}

Tabel 9 Karakteristik Waktu dengan Penyebab Kematian Akibat Asfiksia RSUD Tugurejo Semarang Tahun 2014

\begin{tabular}{clcc}
\hline \multirow{2}{*}{ No } & \multicolumn{2}{c}{ Karakteristik Waktu } & \multicolumn{2}{c}{ Penyebab Kematian } \\
\cline { 3 - 4 } & Lama Dirawat & $38(84,4 \%)$ & Non Asfiksia \\
\hline a. $<48$ Jam & $40(88,9 \%)$ & $5(15,6 \%)$ \\
& b.>48 Jam & & \\
2 & Jarak Anak & $31(83,8 \%)$ & $6(16,2 \%)$ \\
& a.Anak Pertama < 2 th,> 4 th & $47(88,7 \%)$ & $6(11,3 \%)$ \\
\hline
\end{tabular}

Berdasar Tabel 9 lama dirawat lebih dari 48 jam sebesar 40 (88,9\%) neonatal yang mengalami asfiksia dibanding $5(11,1 \%)$ yang non-asfiksia. Hal ini berhubungan dengan bahwa neo-natal sudah mendapat pertolongan selama di rumah sakit dibandingkan bila kematian sebelum 48 jam yang biasanya disebabkan akibat kurang berfungsinya rujukan.

Jarak anak antara persalinan ini denan kehamilan sebelumnya sebesar 78 $(86,7 \%)$ yang ternyata mengalami asfiksia sehingga mengakibatkan kematian pada neo-natal dibandingkan $12(13.3 \%)$ yang non-asfiksia. Jarak anak 2 s/d 4 tahun adalah jarak yang sempurna untuk kehamilan dan persalinan, dengan jarak ini diharapkan ibu dan bayi yang dilahirkannya sehat.

\section{Review Karakteristik Orang, Tempat dan Waktu dengan Kematian Neonatal Akibat Asfiksia}

Tabel 10 Hasil Uji Bivariat Karakteristik Orang, Tempat dan Waktu dengan Kematian Neonatal Akibat Asfiksia Di RSUD Tugurejo Semarang Tahun 2014

\begin{tabular}{clcc}
\hline NO & \multicolumn{1}{c}{ KARAKTERISTIK } & P value & OR \\
\hline 1 & Orang ( Neonatal ) & & \\
& a. Umur Neonatal & 0,004 & 6,250 \\
& b.Jenis Kelamin & 0,453 & 0,614 \\
& c. Berat Badan Lahir & 0,104 & 2,714 \\
\multirow{2}{*}{$2 \quad$ d.Panjang Badan Lahir } & 0,442 & 0,442 \\
& Orang (Ibu Neonatal) & & \\
& a. Umur Ibu & 0,348 & 0,560 \\
& b. ANC & 0,899 & 1,083 \\
& c. Usia Kehamilan & 0,432 & 1,474 \\
d. Paritas & 0,053 & 0,296 \\
& e. Pendidikan Ibu & 0,027 & 3,875 \\
& f. Komplikasi Kehamilan & 0,037 & 3,588 \\
g. Komplikasi Persalinan & 0,008 & 5,000
\end{tabular}




$\begin{array}{lll}3 & \text { Karakteristik Tempat : } & \\ \text { a. Asal Ibu } & 0,930 & 1,060 \\ \text { b. Akses Ke Rumah Sakit } & 0,320 & 0,526 \\ 4 & & \\ \text { Karakteristik Waktu } & 0,535 & 0,581 \\ \text { a. Lama Dirawat } & 0,027 & 3,875 \\ \text { b. Jarak Anak } & & \end{array}$

Pada tabel 10 percobaan dengan uji statistik Chi Square didapatkan hasil nilai $\mathrm{p}$ value dibawah 0,005 yang berarti ada hubungan antara asfiksia dengan karakteristik neonatal, karakteristik ibu dan karakteristik tempat serta karakteristik waktu adalah : Umur neonatal $(\mathrm{P}$ value $=0,004)$, Pendidikan ibu $(\mathrm{P}$ value $=0,027)$ komplikasi kehamilan $(\mathrm{P}$ value $=0,037)$ dan komplikasi persalinan $(\mathrm{P}$ value $=0,008)$. Tidak ada hubungan kematian neonatal akibat asfiksia berdasarkan karakteristik tempat yang meliputi asal ibu dan akses menuju rumah sakit. Ada hubungan antara jarak anak dengan persalinan sebelumnya $(\mathrm{P}$ value $=0,027)$

Pada penelitian ini kematian akibat asfiksia sebesar 78 (86,7\%) dibandingkan yang non asfiksia sebesar 12 (13,3\%). Asfiksia ditentukan dari nilai Apgar score yang rendah yaitu $0-6$. Apgar score merupakan indikator penting yang dikaitkan dengan risiko kematian neonatal. Score ini tidak hanya berguna untuk mengevaluasi status kondisi kesehatan neo-natal pada menit pertama setelah kelahiran, tetapi juga untuk menentukan sejauh mana kebutuhan bayi untuk resusitasi. Penelitian ini menunjukkan bahwa asfiksia yang ditunjukkan dari nilai apgar score yang rendah mengakibatkan kematian bayi. Beberapa penelitian menyimpulkan bahwa proporsi Apgar score rendah relatif tinggi mengindikasikan tingkat obstetric care dan mutu pelayanan selama persalinan (Unicef Indonesia, 2012).

\section{SIMPULAN DAN SARAN}

\section{Simpulan}

Kematian neonatal akibat asfiksia adalah sebesar $70(90,9 \%)$ pada umur kematian 0-7 hari, 43 (84\%) berjenis kelamin laki-laki, 57 (90,5\%) karena BBLR dan sebesar $60(88,2 \%)$ panjang badan kurang dari $47 \mathrm{~cm}$ atau stunting. Kematian neonatal akibat asfiksia berdasarkan karakteristik ibu yaitu sebesar $50(89,3 \%)$ pada usia 20-35 tahun, sebesar $47(87,0 \%)$ ibu dengan ANC $<4$ kali, usia kehamilan sebesar 42 (88,9\%) adalah 28-37 minggu, multipara dengan 2-4 anak sebesar 49 (92,5\%), pendidikan ibu SD dan SMP sebesar 62 (91,2\%),mengalami komplikasi kehamilan sebesar $61(91,0 \%)$ dan mengalami komplikasi selama persalinan sebesar $65(91,5 \%)$. Kematian neonatal akibat asfiksia berdasarkan karakteristik tempat yaitu sebesar $53(86,9 \%)$ berasal dari pedesaan dan akses ke rumah sakit sebesar $40(83,3 \%)$ kurang dari 2 jam.

Kematian neonatal akibat asfiksia berdasarkan karakteristik waktu lama dirawat sebesar $40(88,9 \%)$ dirawat lebih dari 48 jam dan jarak anak dengan persalinan sebelumnya sebesar $47(88,7 \%)$ merupakan multipara dengan anak 2-4 anak. Penyebab Kematian neonatal akibat asfiksia pada penelitian ini sebesar 78 $(86,7 \%)$ dibandingkan non asfiksia sebesar 12 (13,3\%). Pada uji bivariat 
didapatkan hasil ada hubungan antara umur neonatal $(\mathrm{P}=0,04)$, pendidikan ibu $(\mathrm{P}=0,027)$, komplikasi kehamilan $(\mathrm{P}=0,037)$, komplikasi persalinan $(\mathrm{P}=0,08)$ dan jarak anak $(\mathrm{P}=0,027)$ dengan kematian neonatal karena asfiksi.

\section{Saran}

Penyebab kematian terbesar karena asfiksia ini dan mengingat usia kematian terbesar terjadi pada umur 0-7 hari, diharapkan dapat dicegah dengan cara memperhatikan sistem pelayanan kebidanan dan pediatri terutama dokter jaga yang siap di tempat (on Site) dibandingkan dengan pelayanan on call, sehingga bila ada pasien yang datang untuk dirawat dokter sudah siap ditempat. Pendidikan ibu yang rendah berhubungan dengan kematian neonatal, sehingga perlu ketersediaan informasi baik penyuluhan maupun konseling untuk ibu-iu mengenai bahaya yang dapat terjadi dalam kehamilan, persalinan dan nifas, serta upaya untuk menghindari masalah tersebut dan cara pemecahan masalah. Adanya hubungan komplikasi kehamilan dan persalinan dengan kematian neonatal, ditindak lanjuti dengan regionalisasi pelayanan perawatan ke depan untuk kebidanan dan pediatri sehingga ada pemerataan pelayanan. Program KB kepada para ibu yang kontrol dan berobat perlu digiatkan, sehingga jarak anak menjadi optimal dan gangguan / kematan neonatal akibat jarak yang terlalu dekat atau terlalu jauh dapat dicegah.

\section{DAFTAR PUSTAKA}

Abdullah, Asnawi, dkk. 2015. Faktor Risiko Kematian Neonatal di Provinsi Nusa Tenggara Timur : A Matched Case-Control Study. Kupang : AIPMNH.

Carr, Susan dan Nigel Unwin. 2014. Kesehatan Masyarakat dan Epidemiologi Edisi II. Jakarta : Penerbit Buku Kedokteran EGC.

Dahlan, Sopiyudin. 2011. Statistik untuk Kedokteran dan Kesehatan. Jakarta : Penerbit Salemba Medika.

Dinas Kesehatan Provinsi Jawa Tengah. 2014. Buku Profil Kesehatan Provinsi Jawa Tengah. Semarang.

Hatta, Gemala. 2008. Pedoman Manajemen Informasi Kesehatan di Sarana Pelayanan Kesehatan. Jakarta : Penerbit Universitas Indonesia.

Noor, Nur Nasry. 2008. Epidemiologi (Edisi Revisi). Jakarta : Rineka Cipta

Paula MS, Izildinina M, et all. 2014. Risk Factors for Perinatal Death in Two Different Levels of care. https://www.ncbi.nlm.nih.gov/pmc/articles/PMC3909453/. Diakses tagl 28 Januari 2016.

Prasetyawati, Arsita Eka. 2012. Kesehatan Ibu dan Anak dalam Millenium Development Goals (MDGs). Yogyakarta : Nuha Medika.

Rahani, dkk. Profil Kematian Neonatal Berdasarkan Sosio Demografi dan Kondisi Ibu Saat Hamil di Indonesia. Buletin of Health System Research. Vol. 14 No. 4 Oktober 2011: 391-398.

Sugiharto, Mugeni. 2010. Analisis Perbedaan Antar Paritas Ibu dengan Kematian Neonatal. Buletin Penelitian Sistem Kesehatan. Vol. 13 No. 4 Oktober 2010: 321-325. 
Sumantri, Usman. 2014. Peran Kemenkes dalam Pembinaan PT Bidang Kesehatan. Semarang : Badan PPSDM Kesehatan Kemenkes RI

Triono. 2009. Laporan Hasil Riset Kesehatan Dasar Provinsi Jawa Tengah. Jakarta : Badan Penelitian dan Pengembangan Kesehatan Depkes RI.

Trihono. 2010. Riset Kesehatan Dasar (Riskesdas 2010). Jakarta : Badan Penelitian dan Pengembangan Kesehatan Kemenkes RI.

Trihono. 2013. Riset Kesehatan Dasar (Riskesdas 2013). Jakarta : Badan Penelitian dan Pengembangan Kesehatan Kemenkes RI.

Unicef Indonesia. 2012. Kesehatan Ibu dan Anak. Ringkasan Kajian Terbit Oktober 2012. Jakarta : Unite for Children

Utomo Tri dkk. 2011. Risk Factors for Birth Asphyxia, Folia Medica Indonesia, vol 47.no.4, Oktober - Desember 2011.

Zulkifli, Andi. 2012. Faktor Risiko Kematian Neonatal Dini Di Rumah Sakit Bersalin. Bagian Epidemiologi FKM Unhas. 